\author{
Petre ILTCHEV ${ }^{1}$, \\ Anna PIECHOTA ${ }^{2}$, \\ Remigiusz KOZLOWSKI ${ }^{3}$, \\ Michal MARCZAK ${ }^{4}$
}

\title{
THE CAPITAL MARKET AS A SOURCE OF FINANCING FOR SMALL INNOVATIVE COMPANIES IN THE MEDICAL INDUSTRY
}

\begin{abstract}
The objective of the paper is to present the possibilities of financing the development of companies in the pharmaceutical, biotechnological, and medical sectors through the capital market. The trading prices of selected companies on the Polish stock exchanges (NewConnect and WSE) are discussed. Furthermore, the work analyzes the evolution of the WSE in the years 2007-2015 with a particular focus on the trading volumes and the maximum and minimum prices of the stocks of selected biotechnological and medical companies between January 2015 and April 2016. Using DbNotowania software from Statica, the selected companies were analyzed visually to identify abnormal price changes. Data were obtained from the at-skaner.pl database, normalized, and imported to Microsoft Access for more detailed analysis. It was concluded that the WSE may play a more prominent role in the development of innovative biotechnological, pharmaceutical, and medical companies if the changes recommended in this paper are implemented. Given the tendency towards capital market consolidation, it is logical that following an IPO on less liquid markets, companies will gradually try to transition to the more liquid ones. It would be advisable for small innovative companies to attract the attention of recommendation-issuing companies such as Edison Investment Research. The government should encourage individual and institutional investors to participate and finance the Polish capital market by appropriate regulations and tax exemptions.
\end{abstract}

Keywords: Polish biotechnology companies, Polish capital market, Financing Small innovative companies

\section{INTRODUCTION}

Innovative companies in the medical, biotechnological, and pharmaceutical industries face considerable difficulties acquiring capital. The development of new drugs in the preclinical phase (prior to approval) and the commercialization of new medical solutions, technologies, and equipment entail a high risk of failure. Due to that, financial institutions

\footnotetext{
${ }^{1}$ PhD, Public Health Department, Health Sciences Faculty, Medical University of Lodz, Lindleya 6, 90-131 Lodz, Poland, e-mail: petre.iltchev@gmail.com

${ }^{2} \mathrm{PhD}$, Institute of Finance, Faculty of Economics and Sociology, University of Lodz, 3/5 POW Street, 90-255 Lodz, Poland, e-mail: anna_piechota07@wp.pl

${ }^{3}$ Prof. , DSc, PhD, Eng.,Department of Logistics, Faculty of Management, University of Lodz, 22/26 Matejki Street, 90-237 Lodz, Poland, e-mail: remigiusz@uni.lodz.pl

${ }^{4}$ DSc, PhD, Associate Prof. UMED of Lodz, Health Care Policy Department, Health Sciences Faculty, Medical University of Lodz, Lindleya 6, 90-131 Lodz, Poland, e-mail: michal.j.marczak@gmail.com
} 
are reluctant to finance the operations and development of such companies, which take recourse to grants and the capital market.

The objective of the paper is to analyze high-technology companies in the pharmaceutical, biotechnological, and medical companies listed on Polish stock exchanges, that is NewConnect and the Warsaw Stock Exchange (WSE). NewConnect is a stock exchange for companies which publish simplified financial reports, thus exposing the investors to higher risk. This exchange is much less liquid than the WSE. Table 1 gives a classification of investors in the Polish capital market by capital source and investor type.

Table 1 Classification of investors in the Polish capital market

\begin{tabular}{|l|l|l|}
\hline Type of investor / capital & Domestic & Foreign \\
\hline Institutional & $\begin{array}{l}\text { Open pension funds, in- } \\
\text { vestment funds, venture } \\
\text { capital funds }\end{array}$ & $\begin{array}{l}\text { Investment fund associa- } \\
\text { tions, sovereign funds } \\
\text { (e.g., Norges Bank) }\end{array}$ \\
\hline Individual & & \\
\hline
\end{tabular}

Source: Own work

There are no exact data on the percentage contribution of foreign capital from individual investors to the WSE trading volume. It should be noted that a foreign investment is largely affected by the PLN to USD and EUR exchange rates as well as by the prevalent sentiment towards the emerging markets (including Poland). Due to risk considerations and investment goals, individual and institutional investors may adopt different time horizons. As entry or exit decisions may be influenced by all factors and information pertaining to the emerging markets, investors pay great attention not only to potential profits, but also to the liquidity of company securities. Furthermore, the WSE is not always able to ensure financing to small and medium-sized innovative companies without exposing them to the risk of takeover by larger corporations. Other negative issues affecting the stock exchange in Poland include:

- low stock liquidity and trading volumes, which may lead to unwarranted large price fluctuations;

- insufficient presence of institutional investors;

- absence of international companies monitoring the various market segments and issuing recommendations for individual company stocks.

Of interest to this paper are the following questions:

- What trading volume can lead to an increase or decrease in stock prices?

- Do the innovative companies in the medical industry listed on NewConnect and the WSE differ in terms of their stock liquidity?

- If companies transition to the WSE, does this lead to higher trading volumes? If so, what is the difference?

- In what ways do the proportions of shares owned by the company's founders and top managers, as well as institutional investors (holding at least 5\% of the stock) affect stock liquidity? What is the relationship between the free float volume and stock liquidity?

The selected companies were analyzed based on daily data characterizing stock exchange transactions, that is, trading prices and volumes for January 2015-March 2016, 
obtained from the Google Stock Screener ${ }^{5}$ database. In order to enable international comparisons, all variables were converted into EUR at the exchange rates as of the end of a given period, quoted on the WSE website ${ }^{6}$.

\section{RESEARCH METHODOLOGY}

Innovative products or exports accounting for at least $50 \%$ of a company's sales were adopted as criteria for innovativeness. Trading price and volume changes following a transition from NewConnect to the WSE, as well as minimum and maximum trading prices were analyzed. The two Polish stock exchanges, NewConnect and the WSE were compared based on analysis of some indicators characterizing the capital market for innovative companies in the medical industry. Using DbNotowania software from Statica, the selected companies were analyzed visually to identify abnormal price changes.

Data obtained from the Google Stock Screener database were normalized in a spreadsheet prior to importing to MS Access (spaces between digits and the abbreviation "zl" were removed, numbers were formatted to display two decimal places. The data on the transactions of all companies were imported as an external table. Using MS Access 2010, periods of abnormal price changes were analyzed in greater detail. To facilitate analysis and the investment decision-making process, daily tables were aggregated into monthly ones.

The advantage of adopting volume as a criterion of liquidity is that it enables easy comparison of companies with different capitalizations. By dividing the average daily trading volume by the number of listed companies, one can obtain the "average" daily volume per one listed company. In turn, that divided by the average value of one transaction returns the daily number of transactions. It is difficult to use the $\mathrm{P} / \mathrm{E}$ indicator for innovative start-ups as for the first several years they generally do not generate revenues. Therefore, the methodology described by Goedhart, Koller, and Wessels ${ }^{7}$ seems to be more appropriate.

To analyze the effect of transitioning between the stock exchanges, innovative companies in the medical industry were selected from NewConnect and the WSE.

\section{BRIEF CHARACTERIZATION OF WSE DEVELOPMENT IN 2007-2015}

Prior to analyzing the selected innovative companies in the medical sector, a brief characterization of WSE development in the years 2007-2015 is given. If investors wish to exit a company, they must sell the shares they hold. If the company stock is not liquid, the sale may extend over several days or lead to a dramatic drop in the share price. In that event, losses are incurred not only by the exiting investor, but also by the company concerned. The lack of stock liquidity hinders accurate assessment of the company's value, which may easily be over- or under-estimated without actual reasons based on company operations and prospects.

\footnotetext{
${ }^{5}$ Google Stock Screener. Online: https://www.google.com/finance\#stockscreener. Accessed, 2.03.2016.

${ }^{6} \mathrm{GPW}$. Podstawowe statystyki GPW. Online:

https://www.gpw.pl/analizy_i_statystyki_pelna_wersja Accessed 24.02.2016.

7 M. Goedhart, T. Koller, D. Wessels. Valuing high-tech companies. McKinesy. 2016. Online: http://www.mckinsey.com/Business-Functions/Strategy-and-Corporate-Finance/Our-Insights/Valuing-hightech-companies?cid=other-eml-alt-mip-mck-oth-1602. Accessed 24.02.2016
} 
A major influence on the Polish capital market has been exerted by open pension funds, which can be illustrated with data on the amount of money they collected ${ }^{8}$. Table 2 shows the investor structure on the WSE.

As can be seen from Table 2, the average annual volume in 2015 amounted to only $75 \%$ of that in 2007. In 2015, the average transaction value dropped to 2,903 EUR, which was by $31.29 \%$ less than in 2007 . Furthermore, in 2015 the average daily trading volume per company was 39,257 EUR, which means a $46.37 \%$ decline as compared to 2007 . The criterion of company liquidity was adopted as a daily volume of at least 100,000 EUR, which corresponded to approx. 34 transactions a day in 2015 (it should be noted that under this criterion, daily volume depends on the trading prices of the stock of a given company). In 2015, this parameter reached 13.5 transactions daily. This shows that in the studied period stock liquidity exhibited a decreasing tendency on the WSE. Obviously, the companies included in the WIG20 index had much higher trading volumes (are much more liquid) than companies included in the mWIG80 index.

A comparison on averaged data for selected innovative companies in the medical industry enables a more accurate assessment of the possibility of their financing through the WSE.

One shortcoming of the statistics given in Table 2 is that foreign investors are not subdivided into individual and institutional ones. However, it is the latter that play a decisive role in financing the development of new innovative companies. Indeed, they are often the next step in the financing cycle, following grants and venture capital. The basic prerequisites for individual and foreign investors to take interest in small and medium-sized companies on the stock exchange are:

- for the company founders and top managers to own approx. half of the capital;

- for institutional investors to hold approx. 20-30\% of the capital.

Unfortunately, the number of individual investors is on the decline. While it is them who saved the WSE in 2009, at a time when foreign investors and Polish institutional investors were selling out, since then their share in the trading volume on the WSE has decreased, to reach a minimum in 2015. The WSE primarily lists Polish companies and if their development is to be financed by Polish institutional and individual investors, appropriate conditions must be created. Otherwise, the WSE is poised to face a continuing downward trend in trading volume. A factor that may limit the contribution of Polish individual investors to financing innovative companies through the WSE is insufficient capital among the general population. The inhabitants of countries with emerging markets, such as Poland, have much lower disposable resources, both in relative and absolute terms, than those of the developed countries, mostly due to:

- a lower level of socioeconomic development;

- much lower incomes per capita than in OECD countries.

\footnotetext{
8 M. Stopka, 2016. Rekordowa dziura budżetowa $i$ nadwyzka: Polska $i$ Niemcy. Online: http://www.michalstopka.pl/rekordowa-dziura-budzetowa-i-nadwyzka-polska-i-niemcy. Accessed 24.02.2016.
} 


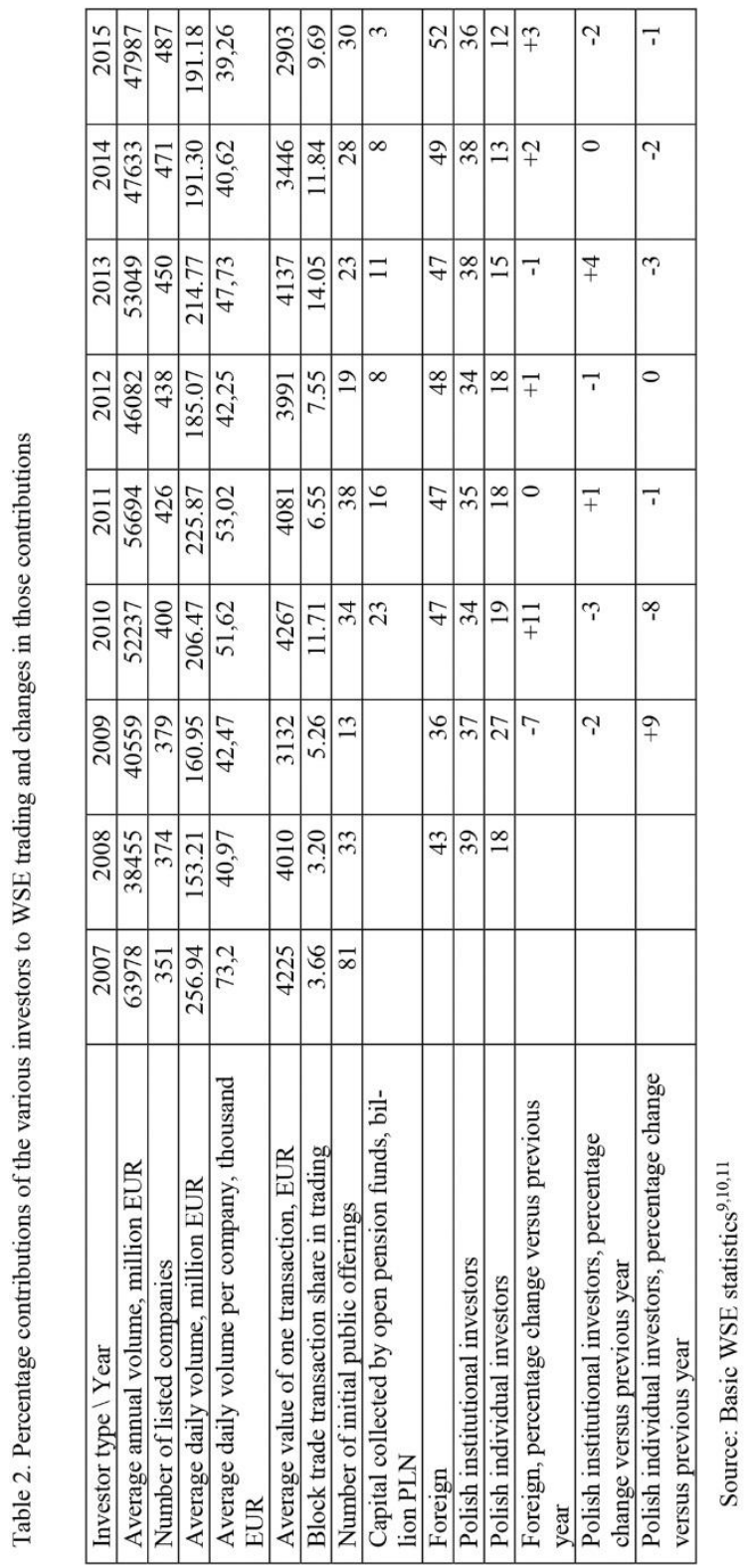

Source: Basic WSE statistics ${ }^{9,10,11}$

\footnotetext{
${ }^{9}$ M. Stopka, op. cit.

${ }^{10}$ P. Cymcyk. 2016. Udziat inwestorów w handlu na GPW. DNA Rynków. 29022016 roku. Online: http://dnarynkow.com/2016/02/29/inwestor-gatunek-zagrozony/ Accessed 24.02.2016.

${ }^{11}$ GPW. Podstawowe statystyki GPW. Online: https://www.gpw.pl/analizy_i_statystyki_pelna_wersja Accessed 24.02.2016.
} 
Research shows that following the reversal of the pension reform and limitation of the freedom of open pension funds, the "Average annual volume, million EUR" on the WSE decreased by $25 \%$ in the period $2007-2015$ year (Table 2 ).

Investors are not always interested in the financing of the development of small innovative companies due to the following features of the Polish capital market:

- Absence of tax exemptions for entities investing in small innovative companies; all investors pay a capital gains tax amounting to $19 \%$.

- The information that companies are required to divulge to the investors is highly insufficient. Companies are not obligated to communicate frequently (except for some cases defined in relevant regulations). Moreover, companies often ignore queries from investor organizations and associations, such as the Association of Individual Investors.

\section{BRIEF CHARACTERIZATION OF INNOVATIVE COMPANIES IN THE BIOTECHNOLOGICAL, PHARMACEUTICAL, AND MEDICAL INDUS- TRIES}

A short description of innovative companies in the biotechnological, pharmaceutical, and medical industries will enable a better understanding of the role of the capital market (the WSE) in financing their development.

In selecting companies for analysis, we excluded those financing health care entities (MAGELLAN, MWTRADE) and distributors of medical products (PELION, FARMACOL, NEUCA) as well as companies which own or operate hospitals or clinics (ENEL-MED, SWISSMED, SCANMED MULTIMEDIS). Brief characteristics of the selected companies are given below:

Mabion Poland SA is "a leading biotechnology company that was created in order to market the latest generation of biotech drugs based on humanized monoclonal antibodies" 12 .

Medicalgorithmics S.A. offers a solution termed PocketECG, which employs mobile technologies to monitor and analyze heart function, with its main markets being the United States and Asia ${ }^{13}$.

The main area of activity of the Inno-Gene Capital Investment Group is "the genetic testing market in Poland, with time, around the world"14.

The business of the Cormay Group is the development and manufacturing of diagnostic reagents and laboratory analyzers (blood, urine) ${ }^{15}$.

Milestone Medical Inc. is a joint venture "for the development, commercialization, manufacturing and marketing of epidural and intra-articular injection instruments"16.

Selvita can be described as "a drug discovery company engaged in the research and development of breakthrough therapies in the area of oncology, as well as provision of integrated drug discovery services" ${ }^{\prime 17}$.

\footnotetext{
${ }^{12}$ Mabion S.A. https://mabion.eu/en. Accessed, 27.03.2016.

${ }^{13}$ MEDICALgorithmics S.A.. Pocket ECG. Online: http://www.medicalgorithmics.com. Accessed, 2.03.2016.

${ }^{14}$ Inno-Gene S.A. Group. About us. http://wwww.en.inno-gene.eu/about-us. Accessed, 27.03.2016.

${ }^{15}$ Cormay Group.About Cormay Group.http://cormay.eu/ Accessed, 27.03.2016.

${ }^{16}$ Milestone Medical. Company Overview.http://www.medicalmilestone.com/Accessed,27.03.2016.

${ }^{17}$ Selivta S.A. Company profile. http://www.selvita.com/about-us/about-us. Accessed, 27.03.2016.
} 
Pahrmena SA, being part of the Pelion Group ${ }^{18}$, is focused on the research and commercialization of anti-atherosclerosis drugs, dietary supplements, and dermocosmetics ${ }^{19}$.

Small innovative companies usually access the stock market through NewConnect, which requires only limited reporting from the listed companies. However, by the same token, the investors do not have complete information needed for decision-making and thus run a higher risk than those investing on the WSE. Due to the absence of mechanisms protecting the interests of small investors, they typically lose all their capitals in the event of company bankruptcy ${ }^{20}$. Additional investment risk is attributable to the fact that the technologies and medicinal products being developed may not be approved by the FDA, EMA, etc. Once the medical product successfully passes clinical trials, biotechnological / pharmaceutical companies greatly accelerate their growth, with a concomitant increase in the trading prices of their stocks and capitalization (higher company value $)^{21}$. The initial public offering implies the risk of share prices falling below the IPO levels ${ }^{22}$, which is more likely in a volatile market ${ }^{23}$.

Insufficient stock liquidity, implying difficulties with converting the invested capital into cash, is particularly severe in the case of innovative companies in the medical sector. Other important data concern the relationship between price fluctuations and stock volume. Table 3 provides such data for selected companies in the medical industry.

It should be determined whether the maximum and minimum trading prices were actually influenced by information concerning the company. In that case, those changes should be accompanied by increased trading volumes. However, as it can be seen from Table 3, in the case of Inno-gene S.A., Milestone Medical, Pharmena and Selvita trading price fluctuations occurred at low volumes, which means that a decisive role was played by speculators. Small innovative companies are exposed to the risk of their stocks being accumulated by their competitors at times of price drops, leading to the risk of a hostile takeover. The table shows that the trading prices of company stocks can be influenced by investors with very low amounts of capital, which is very detrimental to companies whose management board does not own sizeable capital.

Such situations are aggravated under adverse macroeconomic situations. The small number of transactions and low liquidity prevent the use of the methods described by Steinki and Mohammad ${ }^{24}$. Even in developed markets, such as Great Britain, investors are

18 Pelion Healthcare Group SA. Acquisition by Pelion Group of control of its associate Pharmena S.A.http://www.pelion.eu/en/current_reports/0/11384.htmlAccessed, 27.03.2016.

19 Pharmena SA. Research.http://www.pharmena.eu/ Accessed, 27.03.2016.

20 F. Kowalik. Kto pomaga inwestorom na GPW tracić pieniądze. Forbes. 06.11.2015. Online: http://www.forbes.pl/inwestorzy-na-gpw-traca-pieniadze-warszawska-gielda-wkryzysie,artykuly, 199892,1,1.html. Accessed 24.02.2016.

21 B. Orelli. 9 Things you need to know about biosimilar drugs. The Motley Fool. 2016. Online:http://www.nasdaq.com/article/9-things-you-need-to-know-about-biosimilar-drugs-cm598394. Accessed, 27.03.2016.

${ }^{22}$ T. Yuko, T. Hasegawa. Japanese IPOs Struggle to Gain Ground. BloombergBusiness. March 27, 2016. Online: http://www.bloomberg.com/news/articles/2016-03-27/woes-descend-on-japanese-ipos-as-stocks-tank-at-startof-trading. Accessed, 27.03.2016.

${ }^{23}$ O. Steinki, M. Ziad. Common metrics for performance evaluation: overview of popular performance measurement ratios. Evoltiq. 2015. Online https://www.academia.edu/16470851/Common_Metrics_for_ Performance_Evaluation_Overview_of_Popular_Performance_Measurement_Ratios Accessed, 20.03.2016.

${ }^{24}$ Ibidem 
sensitive to external signals $\mathrm{s}^{25}$. Therefore, alternative ways of financing innovative companies in the medical sector should be considered. For instance, venture capital offers some advantages to small and medium-sized companies over the stock market; these include:

- venture capital investors work with the company for several years;

- company managers learn from the venture capital investors and accumulate experience in terms of management, marketing, etc., which is often more important than financing itself.

Finally, the acquisition of a small innovative company by a large corporation represents an alternative to venture capital or indeed, an exit strategy following a round of venture capital financing. An example here is Iwona Software, which was acquired by Amazon $^{26}$.

Small companies which would like to enter the stock market should consider the consequences of the merger of the Deutsche Börse with the London Stock Exchange ${ }^{27}$ as that event may have ramifications even for such players as the Euronext stock exchange. Given the tendency towards capital market consolidation, it is logical that following an IPO on less liquid markets, companies will gradually try to transition to the more liquid ones. If this happens, the WSE may become marginalized as investors move elsewhere. Examples of companies which already follow that trend with a view to acquiring more capital include WorkService with dual listing on the WSE and the LSE and LiveChat aiming at transitioning to Nasdaq.

It would be advisable for small innovative companies to attract the attention of recommendation-issuing companies such as Edison Investment Research ${ }^{28}$. The development of a Market Volatility Index for biotechnological and medical companies and a comparison with a corresponding index for the WSE and WIG20 companies would allow investors to make more rational decisions ${ }^{29,30}$.

\footnotetext{
${ }^{25}$ J. Kahn, A. Satariano. Brexit Nerves Cost This London Tech Startup \$142,00i0 Already. Bloomberg. March 9 , 2016. Online http://www.bloomberg.com/news/articles/2016-03-09/-brexit-nerves-cost-this-london-techstartup-142-000-already. Accessed, 27.03.2016.

${ }^{26}$ Ivona Software. Online: https://www.ivona.com/us/about-us/company. Accessed, 20.03.2016.

27 J. Detrixhe. Exchanges Talk Marriage While Their Nations Contemplate Divorce. Online: http://www.bloomberg.com/news/articles/2016-02-24/exchanges-talk-marriage-while-their-nationscontemplate-divorce. Accessed February 24, 2016.

28 Edison Investment Research Limited. Online: http://www.edisoninvestmentresearch.com. Accessed, 27.03.2016.

${ }^{29}$ M. Kiran. Stock Market Volatility during the 2008 Financial Crisis. The Leonard N. Stern School of Business. Glucksman Institute for Research in Securities Markets. April 1, $2010 . \quad$ Online: http://www.stern.nyu.edu/sites/default/files/assets/documents/uat_024308.pdfAccessed, 20.03.2016.

${ }^{30}$ H. Chau. The VIX and its applications in the market. 2012. Online:http://citeseerx.ist.psu.edu/viewdoc/ download?doi=10.1.1.474.5304\&rep=rep1\&type $=$ pdf
} 


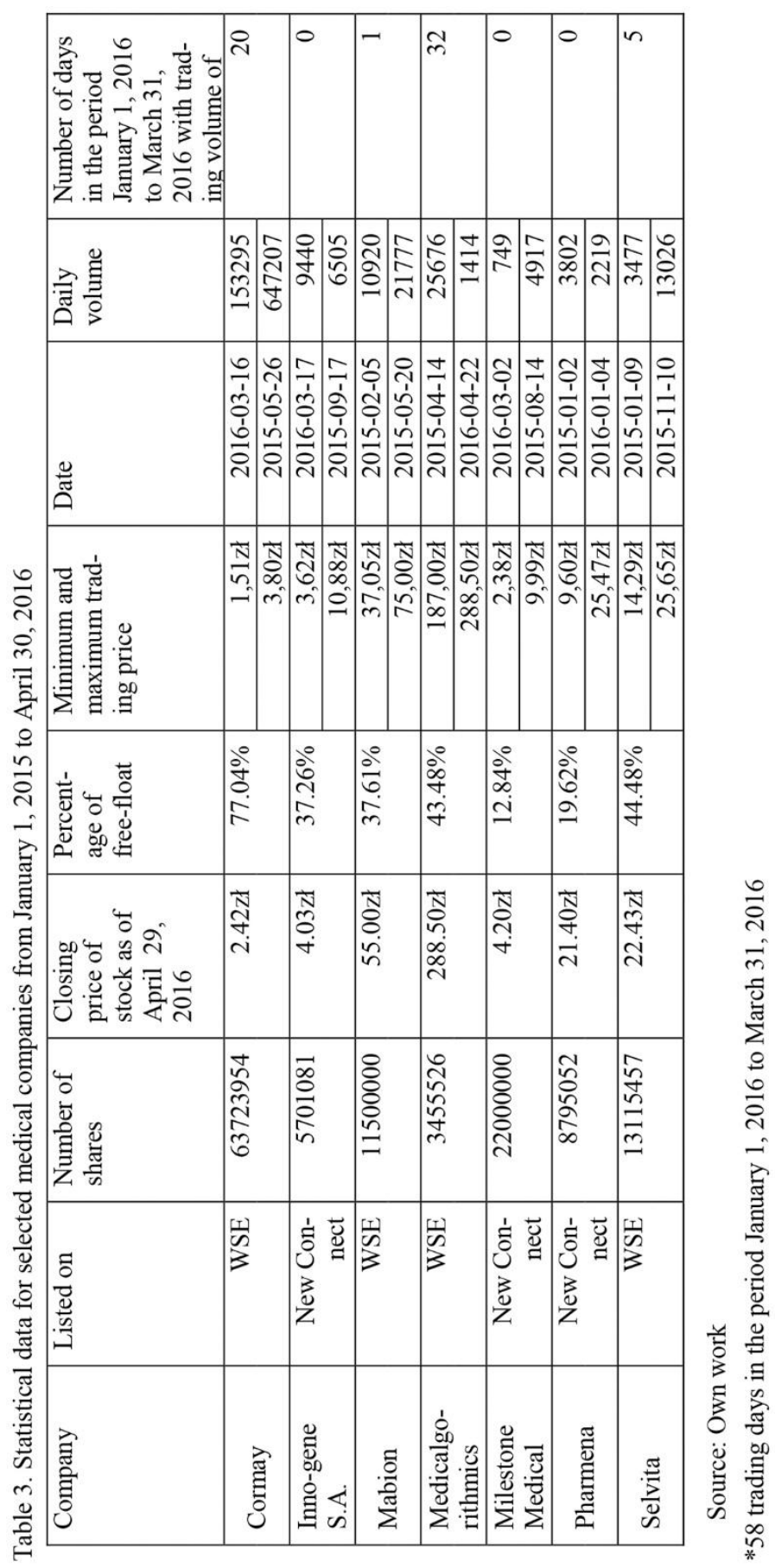




\section{CONCLUSIONS}

The WSE may play a more prominent role in supporting the development of innovative companies in the biotechnological, pharmaceutical, and medical industries. The first step towards solving any problem is its identification. Based on the analysis presented above, the following conclusions may be formulated:

1. Companies which do not exhibit stock liquidity above a certain threshold, such as 50,000 or 100,000 EUR daily should consider withdrawing from the WSE. That would improve the average liquidity of the companies listed on the WSE, thus helping to attract new domestic and international investors.

2. If individual and institutional investors become convinced as to the potential of small innovative companies and increase their liquidity, those companies are also likely to draw the attention of foreign investors.

3. If the company's stock is not sufficiently liquid, technical analysis does not make much sense.

4. When developing their strategies of financing through the capital market, Polish innovative companies in the medical sector must take into account the consequences of capital market consolidation in Europe ${ }^{31}$.

5. Venture capital funds offer an alternative to the WSE.

6. Investors, including foreign ones, using the DeGiro platform, cannot access NewConnect. This means that access to the shares of Innogen and Milestone Medical, listed on that stock exchange, is limited as compared to Selvita and Mabion, which are listed on the WSE.

7. The government should encourage individual and institutional investors to participate and finance the Polish capital market by appropriate regulations ${ }^{32}$ and tax exemptions.

\section{REFERENCES}

[1] Chau Hy. 2012. The VIX and its applications in the market. Online:http://citeseerx.ist.psu.edu/ viewdoc/download?doi=10.1.1.474.5304\&rep=rep1\&type=pdf Accessed, 20.03.2016.

[2] Cymcyk Paweł. 2016. Udziat inwestorów w handlu na GPW. DNA Rynków. 29022016 roku. Online: http://dnarynkow.com.2016/02/29/inwestor-gatunek-zagrozony Accessed, 20.03.2016

[3] Detrixhe John. 2016. Exchanges Talk Marriage While Their Nations Contemplate Divorce. Online: http://www.bloomberg.com/news/articles/2016-02-24/exchanges-talk-marriage-whiletheir-nations-contemplate-divorce. Accessed February 24, 2016.

[4] Detrixhe John. 2016. London Stock Exchange, Deutsche Boerse Agree on Merger. Bloomberg. March 16, 2016. http://www.bloomberg.com/news/articles/2016-03-16/lse-agrees-to-mergewith-german-rival-to-create-european-titan Accessed 17.03.2016.

[5] Goedhart Marc, Koller Tim, Wessels David. 2016. Valuing high-tech companies. McKinesy. Online: http://www.mckinsey.com/Business-Functions/Strategy-and-Corporate-Finance/OurInsights/Valuing-high-tech-companies?cid=other-eml-alt-mip-mck-oth-1602. Accessed 24.02.2016.

\footnotetext{
31 J. Detrixhe. London Stock Exchange, Deutsche Boerse Agree on Merger. Bloomberg. March 16, 2016. http://www.bloomberg.com/news/articles/2016-03-16/lse-agrees-to-merge-with-german-rival-to-createeuropean-titan Accessed 17.03.2016.

32 ISBnews - Biznes. GPW przedłuża okres niższych opłat transakcyjnych. 29 Mar 2016, Online http://stooq.pl/n/?f=1030680 Accessed, 29.03.2016.
} 
[6] ISBnews - Biznes. GPW przedłuża okres niższych opłat transakcyjnych. 29 Mar 2016, Online http://stooq.pl/n/?f=1030680 Accessed, 29.03.2016.

[7] Kahn Jeremy, Satariano Adam. 2016. Brexit Nerves Cost This London Tech Startup \$142,00i0 Already. Bloomberg. March 9, 2016. Online http://www.bloomberg.com/news/articles/201603-09/-brexit-nerves-cost-this-london-tech-startup-142-000-already. Accessed, 27.03.2016.

[8] Kowalik Filip. 2015. Kto pomaga inwestorom na GPW tracić pieniadze. Forbes. 06.11.2015. Online: http://www.forbes.pl/inwestorzy-na-gpw-traca-pieniadze-warszawska-gielda-wkryzysie, artykuly,199892,1,1.html. Accessed 24.02.2016.

[9] Manda Kiran. 2010. Stock Market Volatility during the 2008 Financial Crisis. The Leonard N. Stern School of Business. Glucksman Institute for Research in Securities Markets. April 1, 2010. Online: http://www.stern.nyu.edu/sites/default/files/assets/documents/uat_024308.pdf Accessed, 20.03.2016.

[10] Orelli Brian. 2016. 9 Things you need to know about biosimilar drugs. The Motley Fool. Online:http://www.nasdaq.com/article/9-things-you-need-to-know-about-biosimilar-drugscm598394. Accessed, 27.03.2016.

[11] Steinki Olivier, Mohammad Ziad. 2015. Common metrics for performance evaluation: overview of popular performance measurement ratios. Evoltiq. Online https://www.academia.edu/ 16470851/Common_Metrics_for_Performance_Evaluation_Overview_of_Popular_Performan ce_Measurement_Ratios Accessed, 20.03.2016.

[12] Stopka, Michał. 2016. Rekordowa dziura budżetowa i nadwyżka: Polska i Niemcy. Online: http://www.michalstopka.pl/rekordowa-dziura-budzetowa-i-nadwyzka-polska-i-niemcy. Accessed 24.02.2016.

[13] Takeo Yuko, Hasegawa Toshiro. 2016. Japanese IPOs Struggle to Gain Ground. BloombergBusiness. March 27, 2016. Online: http://www.bloomberg.com/news/articles/201603-27/woes-descend-on-japanese-ipos-as-stocks-tank-at-start-of-trading.

Accessed, 27.03.2016.

Disclaimer: The views, opinions, and information expressed in this article are those of the authors and do not necessarily reflect the official policy or position of any company stakeholders, financial analysts or professionals. The paper is intended for educational purposes for understanding of the Polish stock market. We are in no way recommending the investment, purchase, sale of any stocks of selected in the paper companies, according to the Dz. U. Nr 206 from year $2005^{33}$. The examples of analysis performed within this article are only examples. They should not be utilized to make stock portfolio or financial decisions as they are based only on limited information.

\section{GIELDA PAPIERÓW WARTOŚCIOWYCH, JAKO ŹRÓDŁO FINANSOWANIA MAŁYCH FIRM INNOWACYJNYCH Z BRANŻY MEDYCZNEJ}

Celem artykułu jest przedstawienie możliwości finansowania rozwoju firm z branży farmaceutycznej, biotechnologicznej i medycznej za pomocą rynku kapitałowego. Przedstawiono notowania wybranych firm na polskich rynkach kapitałowych - New Connect oraz GPW. Analizowano rozwój GPW w okresie 2007 - 2015 r. w celu przedstawienia ewolucji polskiego rynku kapitałowego. Szczególną uwagę poświęcono wolumenom oraz najwyż-

\footnotetext{
${ }^{33}$ Rozporządzenie Ministra Finansów z dnia 19 października 2005 r. w sprawie informacji stanowiących rekomendacje dotyczące instrumentów finansowych, ich emitentów lub wystawców. Online: http://isap.sejm.gov.pl/DetailsServlet?id=WDU20052061715. Accessed, 20.03.2016.
} 
szym i najniższym wartościom kursu akcji wybranych firm biotechnologicznych i medycznych w okresie styczeń 2015 - kwiecień 2016. Za pomocą oprogramowania DbNotowania firmy Statica, wybrane firmy analizowano wizualnie w celu zidentyfikowania dużych wahań cenowych. Dane uzyskano z serwisu at-skaner.pl, znormalizowano i zaimportowano do programu Microsoft Access dla bardziej szczegółowej analizy. Firmy innowacyjne z branży medycznej, biotechnologicznej i farmaceutycznej z uwagi na prowadzoną działalność opracowywanie nowych leków często w fazie przedklinicznej lub przed rejestracją, komercjalizacja nowych rozwiązań medycznych mają problem z pozyskiwaniem kapitału. Stwierdzono, że GPW może odgrywać bardziej znaczącą rolę w rozwoju innowacyjnych biotechnologicznych, farmaceutycznych i medycznych firm, jeżeli zostaną zrealizowane zmiany zaproponowane w niniejszym opracowaniu. W warunkach tendencji do konsolidacji rynków kapitałowych logiczne jest, że po debiucie na mniej płynnych rynkach firmy będą się starały stopniowo przychodzić na bardziej płynne. Dobrze jest, aby małe firmy innowacyjne znalazły się w polu uwagi takich serwisów wydających rekomendacje jak Edison Investment Research. Rząd powinien zachęcić inwestorów indywidualnych oraz instytucjonalnych do uczestnictwa i finansowania polskiego rynku kapitałowego poprzez odpowiednie regulacje oraz ulgi podatkowe.

Slowa kluczowe: biotechnologiczne firmy, rynek kapitałowy, finansowanie rozwoju biotechnologicznych firm, giełda papierów wartościowych, inwestowanie na giełdzie

\section{DOI: 10.7862/rz.2016.mmr.46}

Tekst złożono w redakcji: październik 2016

Przyjęto do druku: grudzień 2016 